\title{
From Blue Sky Research to Problem Solving: A Philosophy of Science Theory of New Knowledge Production
}

\author{
Martin Kilduff \\ University of Cambridge \\ mjkilduff@gmail.com
}

\author{
Ajay Mehra \\ University of Kentucky \\ ajay.mehra@uky.edu
}

\author{
Mary B. Dunn \\ University of Texas at Austin \\ mary.bowker.dunn@gmail.com
}

This is a draft version of a paper that has been accepted for publication in Academy of Management Review — it has yet to undergo final editing. The paper may not be reproduced or used in any manner that does not fall within the fair use provisions of the Copyright Act without the prior written permission of Academy of Management Review (http://www.aom.pace.edu/amr/) 


\section{From Blue Sky Research to Problem Solving: A Philosophy of Science Theory of New Knowledge Production}

Rationalized logics developed within discourses of the philosophy of science are examined for implications for the organization of new knowledge. These logics, derived from a range of philosophies (structural realism, instrumentalism, problem solving, foundationalism, critical realism) offer alternative vocabularies of motive, frameworks for reasoning, and guidelines for practice. The paper discusses the kinds of knowledge produced, the indicators of progress, the characteristic methods, exemplar organizations, and ways in which logics are combined and diffused. 
The institution of science is one of the enduring contributors to the modern world providing organized and established procedures for the accomplishment of scientific work. Scientific knowledge is organized knowledge in the sense that its production takes place within and across formal organizational boundaries. Because of the importance of this type of knowledge, there have been many efforts to understand its production (see Hessels \& van Lente, 2008 , for a recent review). But one set of discourses has been neglected by organizational scholars -- those discourses developed within the philosophy of science in answer to the question: what is science (Bortolotti, 2008; Chalmers, 1999)? Within the philosophy of science, there are a range of depictions of scientific activity, depictions that purport to capture the rational process of scientific discovery. These depictions represent alternative logics of action that not only describe in idealized terms actual historical examples of famous scientific breakthroughs, but also prescribe the way scientific activity should be conducted so as to separate true science from pseudoscience (cf. Lakatos, 1970).

Institutionalized logics of action (defined as organizing principles that shape ways of viewing the world -- Suddaby \& Greenwood, 2005: 38) play a fundamental role in providing social actors with vocabularies of motive, frameworks for reasoning, and guidelines for practice. These logics constrain cognition and behavior, but also provide sources of agency and change (Friedland \& Alford, 1991; Rao, Monin \& Durand, 2003: 795; Thornton \& Ocasio, 2008: 101). The purpose of our paper is to examine a range of rationalized logics developed within the discourses of the philosophy of science, logics that profoundly affect the research of professional scientists (Laudan, 1977: 59) through their methods and daily activities (Eddington, 1939, p. vii) as well as through the explanations that scientists "feel compelled" to offer in justification for their practices (Fuller 2003: 93). The justification of scientific activity is increasingly important 
in the modern world (Hilgartner, 2000) in which the boundaries between science and non-science have become eroded (Ziman, 1996) and in which there is an insatiable demand for new scientific knowledge (Gibbons et al., 1994; Nowotny, Scott, \& Gibbons, 2001: 249).

Logics of action are encoded in the routines of training, monitoring, disciplining, and rewarding of professionals (e.g., Friedson, 1970; 2001; Greenwood, Suddaby, \& Hinings, 2002). Founders bring to their new ventures logics of action that continue to influence the structuring and practice of work as the firms grow (Baron, Hannan, \& Burton, 1999). The socialization of new members into existing roles (Van Maanen \& Barley, 1984; Zucker, 1977) through apprenticeships ensures the survival of scientific disciplines (Van Maanen \& Schein, 1979: 211). Logics of action are not only routinized in laboratory practice, they also provide the basis for rhetorical conflict in organizations (Suddaby \& Greenwood, 2005) and can lead to variations in practices within organizations and industries (Lounsbury, 2007). Relevant logics of action offer to culturally competent actors legitimated discourses for the extraction of organizational resources, particularly in fields exhibiting pluralism and change (Dunn \& Jones, 2010; Hardy \& Maguire, 2008) in which basic questions, such as what constitutes a scientific contribution, are often unclear (Overbye, 2002: 7).

It speaks to the legitimated power of discourses within the philosophy of science that these discourses are now routinely invoked in the public sphere in debates concerning science policy (e.g., the debate over global warming -- Maxwell, 2010), business practice (Taleb, 2007) and in legal disputes between organizational factions. Thus, in the celebrated Pennsylvania case in which a school district tried to assert that intelligent design could be taught as an alternative to evolution, philosophers of science appeared for both the plaintiffs and the defendants (Chapman, 2007). 
To clarify the discussion, we focus on new scientific knowledge defined as new theory that articulates or has the potential to articulate new phenomena (Lakatos, 1970). We include within the term "theory" a variety of forms including abductive theory (i.e., theory prompted by surprising observations -- Hanson, 1958) and theoretical models that posit causal relationships among terms (cf. Suppe, 2000). From whence does this new theory derive? We take the view that new knowledge is strongly conditioned by logics of action that incorporate mutual assumptions and orientations. Logics of action are expressed, renewed and changed in social routines and networks characteristic of knowledge communities (cf. Giddens, 1984). As Karl Popper argued: "we approach everything in the light of a preconceived theory" (Popper, 1970: 52). Pre-existing assumptions and orientations that are embodied in logics of action are likely to represent tacit, taken-for-granted backgrounds against which institutional entrepreneurs provide rational explanations of their activities (cf. Misangyi, Weaver, \& Elms, 2008).

Paraphrasing the Thomas theorem (Thomas \& Thomas, 1928: 571-572), we can assert that if scientific knowledge producers see the world through distinctive ontological and epistemological lenses, this way of seeing will have real consequences in terms of the organization of knowledge production. We first derive from the philosophy of science four characteristic logics that represent organizing solutions to the problem of knowledge production (see Figure 1). These representative approaches offer distinctive bundles of assumptions and practices and, we suggest, may have different implications for formal and informal organizing. In building new theory, we formulate empirical predictions concerning how philosophies of science as logics of action are likely to affect organizing processes and outcomes. These empirical speculations represent opportunities for research rather than established verities. 
We suggest, for example, that organizations that produce new knowledge may feature not just one but several or all of the different types of organizing frameworks discussed. A cluster of people gathered together in a department or a laboratory is likely to share a particular logic of action that may be different from logics of action operating in other parts of the organization. Our empirical predictions include comparisons of logics of action with respect to the problems that are likely to be pursued, the indicators of progress that are likely to be used, the characteristic methods each perspective might encourage, and the kinds of organizations that are likely to exemplify each perspective (see Figure 2).

Insert Figure 1 and Figure 2 about here

\section{Logics of Scientific Knowledge Production}

Different positions in the philosophy of science can be organized according to how they deal with basic questions of meaning (i.e., ontology) and knowledge (i.e., epistemology). Ontology concerns the analysis of the types of things or relations that can exist. In science, a major ontological issue concerns whether scientific theories represent reality -- objects, events, and processes outside the human mind; or whether scientific theories comprise explanatory fictions whose terms (such as "electron") are conveniences invented to guide research. Epistemology concerns how one gains access to knowledge and the relationship between knowledge and truth. In science, a major epistemological issue concerns whether or not scientific theories over time move closer and closer to the truth. The ontological question is: Do scientific theories represent reality? The epistemological question is: Does science gets closer and closer to 
the truth? Ontological and epistemological dimensions are represented in Figure 1 in order to highlight some of the major differences between philosophy of science perspectives.

\section{Realist Perspectives}

There are many varieties of realism (Putnam, 1987), but in general they agree that scientific theories aim to provide true descriptions of the world (Okasha, 2002: 59) including the world that lies beyond observable appearances (Chalmers, 1999: 226). Some versions of realism assert that theoretical terms themselves have "putative factual reference" (Psillos, 1999: 11), that terms such as "utility function" refer to real entities. Realist perspectives agree that scientific theories replace each other by offering better accounts of scientific objects (Putnam, 1975) so that over time science gets closer and closer to the truth about the world. Because of the affirmative answers to questions concerning whether scientific theories represent reality, and whether science gets closer to the truth over time, realist perspectives are placed in the top lefthand corner of Figure 1.

Realist perspectives agree, therefore, that there is a real world independent of our social constructions, that it is possible to assess scientific progress toward the truth about this world, and that competing scientific theories can be evaluated rationally in terms of how well they explain significant phenomena about this world. Further, realist perspectives focus on enduring relations between things, typically in the form of mathematical equations.

Structural realism represents a major breakthrough in terms of a logic of action that reconciles two seemingly intractably opposed arguments that have bedeviled arguments for the justification of science (Worrall, 1989). On the one hand, the no miracles argument posits that it would be a miracle -- "a coincidence on a near cosmic scale" (Worrall, 1989:100) -- if a theory made many correct empirical predictions without the theory being basically correct concerning 
the fundamental structure of the world. This view was put forward originally by Poincare (1905) but has been advocated in various forms by many realists (e.g., Popper, 1963; Psillos, 1999; Putnam, 1975). Opposed to this view is the pessimistic meta-induction argument that the history of science is a graveyard of once empirically successful theories (a perspective also anticipated by Poincaré, 1905, as Worrall, 1989, points out). If past scientific theories which were successful were found to be false, we have no reason to believe that our currently successful theories are approximately true (Laudan, 1981).

The reconciliation of these two opposed arguments involves the claim that as theories in mature sciences change, there is a retention of structural content from one theory to the next. For example, the shift from the ether theory of light to the electromagnetic theory of light involved the retention of the mathematical structure expressed in a series of equations such that at the structural level there is complete continuity between the theories (Worrall, 1989). In other cases (such as the transition from Newton's laws to those of Einstein), mathematical equations are retained "as fully determined limiting cases of other equations, in the passing from an old theory to a new one" (Psillos, 1995: 18). Structural realism, therefore, avoids the claim that theories correctly describe the empirical reality of the world (thus defusing the pessimism of the antirealists) but accepts that successful theories are approximately true descriptions of the underlying structure of the world (thus accounting for the miraculous success of science).

Structural realist organizing: The logic of pure research. In order to gain resources and to introduce change into otherwise stable social systems, institutional entrepreneurs "must locate their ideas within the set of existing understandings and actions that constitute the institutional environment" (Hargadon \& Douglas, 2001: 476). The accepted justification for "blue sky" research has typically been couched in terms of a structural realist logic of action. The so-called 
"linear model" or "fable" justifies blue sky research in terms of the necessity of pure research scientists delving into the secrets of nature in the absence of tight controls or specific targets so that potential practical applications can be developed by others in the unspecified future for use by consumers (Grandin, Wormbs, \& Widmalm, 2005). Thus, the knowledge workers who engage in pure research are likely to avoid the tendency to tie their mission to the development of specific inventions. Pure researchers are likely to retain a deep underlying belief in the coherence of their theoretical frameworks. New knowledge is likely to be seen as a long-term project driven by acceptance of causal relations among theoretical terms. The structure of theory from a structural realist perspective remains relatively unchanging, and it is this very stability that can provide the basis for investing time and resources in innovation (Stein, 1989: 57).

Thus, from a structural realist perspective, it is justifiable to organize massive projects aimed at comprehending the structure of the universe. Projects that seek answers to fundamental questions proceed from the assumption that the purpose of science is to map the deep structure of reality, a reality that is typically assumed to be expressible in mathematical form (Ladyman, 1998) or in terms of theoretical models (Suppe, 2000). This unifying assumption facilitates the self-organization of scientists around massive pure research projects, so that hierarchical control is often noticeably absent (Knorr-Cetina, 1999).

The kinds of questions that are likely to be pursued, therefore, from the perspective of structural realism include, most basically, improvements or modifications to fundamental laws (Psillos, 1995) or theoretical models, and attempts to establish evidence to support inferences from such laws. From a structural realist perspective, different ontologies may satisfy the same mathematical or formal structure, and there is no independent reason to believe that one of these ontologies is better than another (Psillos, 1995: 20). But, it is important to remember that the 
structural realist believes that theories inform us about the structure of the world rather than about fictional entities: "realism should involve reference to what 'really' exists" (French \& Ladyman, 2003: 38). Thus, progress from a structural realist perspective involves improvements to our knowledge concerning the structure of reality and the causal relations among entities -although structural realism does not necessarily entail improvements to knowledge concerning the objects and properties of which the world is made (Ladyman, 1998: 422).

Advances in knowledge, according to the logic of structural realism, are likely to be achieved by academic researchers working for universities or research institutions (that may be funded by private companies). These advances are likely to be published in scientific journals devoted to pure research; and, in some cases, registered as patents. Pure research advances are likely to be taken up by other scholars (as measured by citation counts) and by inventors and others seeking to translate academic research into viable products.

We suggest, therefore, that exemplars of a structural realist approach to new knowledge production will tend to be pure-science organizations such as the Large Hadron Collider (LAC) that employs 2250 physicists near Geneva, Switzerland, and involves a further 7750 physicists in research collaborations. Research projects can span decades, with the ultimate goal of understanding the fundamental nature of reality. The LAC is run on a communal basis that involves laborious negotiations among competing groups, and an arrangement by which all research is co-authored by the thousands of physicists involved (Merali, 2010).

In the realm of high-tech companies, a famous example of devotion to relatively pure research was Xerox PARC set up by the Xerox Corporation in a building at the edge of Stanford University in 1970 (hence PARC -- Palo Alto Research Center). The research center hired some of the world's best physicists, mathematicians, materials scientists, computer system architects, 
and software engineers to pursue fundamental discoveries in the "architecture of information" (Chesbrough, 2002: 807). Given millions of dollars to pursue fundamental research, with the understanding that material benefits to Xerox Corporation would not show up for at least a decade, these PARC researchers produced revolutionary discoveries (largely taken up by companies other than Xerox) including the personal computer, a graphical user interface, a laser printer, and technology that would later become indispensable for the spread of the Internet.

\section{Instrumentalist Perspectives}

As its placement in the bottom right-hand corner of Figure 1 indicates, instrumentalism is anti-realist in asserting that scientific theories are useful instruments in helping predict events and solve problems. As one contemporary philosopher of science explained this perspective: "fundamental equations do not govern objects in reality; they only govern objects in models" (Cartwright, 1983: 129). A variety of different labels (instrumentalism, constructive empiricism, theoretical skepticism, and the philosophy of "as if" -- see Horwich, 1991) have been given to the view that one is obliged to believe nothing beyond the observable consequences of a successful scientific theory -- "there can be no reason,..., to give the slightest credence to any of its claims about the hidden, underlying reality" (Horwich, 1991:1). From this perspective, theories should be judged according to how well they help organize phenomena, facilitate empirical prediction, or solve problems in the world (cf. Laudan, 1977; 1990) not on how well they depict "actual" causal processes. Closely related to pragmatism (Sleeper, 1986: 3), instrumentalism treats knowledge as something to be sought, not for its own sake, but for the sake of action to solve problems.

Within the social sciences, this tradition is represented by the neoclassical economics view that theory serves "as a filing system for organizing empirical material" (Friedman, 1953: 
7) and should be judged "by its predictive power" (Friedman, 1953: 8). Important theory tends to provide "wildly inaccurate descriptive representations of reality, and, in general, the more significant the theory, the more unrealistic the assumptions" (Friedman, 1953: 14). Thus, from this instrumentalist perspective, one theory succeeds another not because it moves closer to the truth, but because it represents a more useful predictive framework for the phenomena of interest. We focus here on the problem-solving approach of Larry Laudan that connects the world of scientific theory to the solution of problems in the world. Laudan's philosophy of science is instrumentalist in the sense defined by John Dewey (1903) who established the requirement that theories be reliable and useful tools in practical endeavors such as helping scientists manipulate objects and predict outcomes.

Problem solving. According to Laudan (1977), the question of whether a theory is true or false is irrelevant in determining its scientific acceptability. What is relevant is whether a theory successfully solves problems (Laudan, 1977:18). Further, Laudan rejects the view that the history of science represents a march toward truth about the world. In his view, scientific progress consists in accepting those research traditions which are the most effective in terms of problem-solving (Laudan, 1977: 131). Thus, Laudan's problem-solving approach is representative of the bottom right-hand corner of Figure 1, being anti-realist in terms of ontology, and epistemically instrumentalist in terms of the progress of science.

For Laudan (1977) science consists of competing research traditions that differ from the paradigms discussed by Kuhn (1996) and the research programs discussed by Lakatos (1970) in that all the assumptions of a research tradition can change over time (as the research tradition tackles new and important problems). Further, a research tradition can spawn rival and potentially incompatible theories that compete with each other and with theories produced by 
other research traditions in the solution of problems. This point of view separates rational progress from any question concerning the veracity of theories, because progress consists of increases in problem-solving rather than greater verisimilitude.

From the perspective of the social organization of knowledge production, the problemsolving approach of Laudan (1977) recognizes more clearly than rival approaches the pragmatic nature of scientific progress. Progress involves producing more reliable knowledge rather than knowledge that takes us closer to the truth about the universe (Laudan, 1990:14). From Laudan's perspective, a scientist can participate in two different research traditions, can synthesize a new research tradition from competing alternatives, and, theory born in one research tradition can be separated and moved or taken over by an alternative research tradition which offers more problem-solving capability. Scientists are depicted as pragmatic rationalists who, even as they "accept" theories on the basis of past success in problem-solving, are likely to "pursue" quite different theories (ones that may even seem wildly improbable) if these theories are seen as offering higher rates of problem-solving progress.

Laudan's approach suggests that "a highly successful research tradition will lead to the abandonment of that worldview which is incompatible with it, and to the elaboration of a new worldview compatible with the research tradition" (Laudan, 1977: 101). Thus, what is considered the truth is likely to change to accommodate successful theory. Scientific theories that are unable to counter the claims of prevailing worldviews (even if these worldviews are put forward in nonscientific domains such as religion) are unlikely to be effective. Science, in Laudan's view, is a fluid, flexible, and changing endeavor, in which the successful scientist is able to juggle alternative theories and enter imaginatively into different research traditions, all in the service of problem-solving activity that is at the core of scientific work. 
Instrumentalist organizing: The logic of problem-solving. The problem-solving approach captures the freedom to play around with different theories and different traditions of scientific knowledge production in a way that rival philosophies of science neglect. The overriding prescription of Laudan's approach is to try and discover the theory that has the highest likelihood of solving a particular problem, and this may involve working with research traditions that are mutually inconsistent (Laudan, 1977: 110). The structure of DNA was discovered through scientists playing with molecular models that resembled "the toys of preschool children" (Watson, 1968: 38). From this perspective, scientists have a license to adopt and discard theories and methods to the extent that these theories are useful (cf. Feyerabend, 1975) and socially legitimate without any requirement that they commit themselves paradigmatically (cf. Kuhn, 1996) or that they restrict themselves to a set of unchanging core ideas (cf. Lakatos, 1970).

There is, therefore, an inherent pragmatism in Laudan's approach (Godfrey-Smith, 2003). Although problem-centered organizing does require a certain ideological commitment to whatever theory happens to be guiding empirical inquiry, this commitment is minimal in the sense that theory acceptance does not involve the necessity of believing that the theory is true or that metaphysical unobservables are real.

We suggest, therefore, that the production of new knowledge from this perspective will involve scientists getting on with the pragmatic business of investigating the empirical regularities in nature without having to believe as true the grand metaphysical claims embedded in theories. Problem-oriented scientists faced with conflicting theoretical approaches are likely to compromise in order to "save the phenomena" (Duhem, 1969, first published in 1908) in the sense of providing satisfactory solutions to important problems (Laudan, 1977: 13), irrespective of whether theoretical purity is endangered. Because of the problem-solving focus of this logic of 
action, scientific research from this perspective is likely to be amenable to fortuitous spin-offs from attempts to solve deep intellectual problems (cf. Laudan, 1977: 224). There is a greater likelihood that this logic of action will feature collaborations between university professors and more practically-oriented researchers and designers. For example, in the problem-oriented design firm IDEO, which produces innovative products for 40 industries, the CEO is a professor at Stanford and ten other designers teach product design at the university (Hargadon \& Sutton, 1997).

Indeed, organizations that exemplify a problem-oriented approach to new knowledge production are sometimes created in response to pressing problems. Consider, for example, the hybrid organization that was assembled to devise solutions to the flow of oil pouring into the Gulf of Mexico following the Deepwater Horizon drilling rig explosion on April 20, 2010. This crisis team included physicists, experts on Mars drilling techniques, an expert on hydrogen bombs, and an MIT professor who referenced "going faster on my snowboard" among his research interests. Literally "anyone... who could make a difference was brought in" (a senior BP manager quoted in Tankersley, 2010). Scientific organizations that worked on this cleanup have begun to contribute new theoretical knowledge (e.g., Camilli et al., 2010).

In the realm of high-tech companies, a problem-solving logic of action is, we suggest, exemplified in open source software companies such as Apache, Mozilla, and Linux. These companies operate on the principle that source code is freely available to anyone who wishes to extend, modify or improve it. In the example of Linux, which has developed an operating system for computers, the company centers on the founder Linus Torvalds and 121 "maintainers" who are responsible for Linux modules. There also thousands of user-developers who find bugs and write new pieces of problem-solving code. The success of the company has been explained as 
deriving from the "quantity and heterogeneity of the programmers and users involved in development," a principle that has been dubbed 'Linus's law'. The variety of different code developers and improvers means that problem-solving is approached in many different ways with each problem solver using "a slightly different perceptual set and analytical toolkit, a different angle to the problem" (Raymond, 1999: 43). The open-source software movement has changed our understanding of the sources of innovation in organization, providing a basis for new theory development concerning distributed innovation (von Hippel, 2005).

\section{Foundationalist Perspective}

This perspective occupies the bottom left-hand corner of Figure 1, indicating a combination of anti-realism and the belief that science progresses toward truth. Foundationalist anti-realism was promulgated by logical empiricists influenced by Ernst Mach (1838-1898). Mach "strongly believed that science should deal only in observable phenomena" (Ray, 2000a: 104), claimed "that only the objects of sense experience have any role in science" (Ray, 2000b: 245) and conceived of science as restricted to "description of facts" (Wolters, 2000: 253). The most influential logical empiricist in the Mach tradition, Rudolf Carnap (1891-1970), attempted to construct all domains of scientific knowledge on the basis of individual experience (Carnap, 1928), a perspective that is anti-realist in omitting from the realm of existence theoretical unobservables such as quarks (Creath, 1985: 318). (In contrast, some logical empiricists, such as Hans Reichenbach (1938), moved toward realism by adopting the belief that the physical sciences possess the ontological authority to tell us which entities, properties, and relations can be said to exist -- Crane \& Mellor, 1996). Logical-empiricist anti-realist foundationalism emphasizes empirical data gathering from which scientific knowledge emerges inductively 
(Chalmers, 1999), so that there is a rational basis for evaluating new knowledge claims. Theories with greater empirical content are deemed better than theories with less empirical content.

Foundationalism was one of the most widely debated conceptions of knowledge production prior to the revolutionary ideas of Kuhn (1996, first published in 1962) and is often referred to as the "received view" (Putnam, 1962; Suppe, 1972). Generally, a foundationalist believes there is an ultimate basis in either empirical data or logical process by which knowledge claims can be validated (cf. Ayer , 1952); Kleindorfer, O'Neill, \& Ganeshan, 1998: 1090). This view blends aspects of logical positivism (see Uebel, 1996) and logical empiricism (see McKelvey, 2002) -- indeed, "empiricist philosophies have often had a foundationalist structure" (Godfrey-Smith, 2003: 220). More recently, foundationalist philosophy of science has resurfaced under the rubric of "reliabilism" according to which beliefs are justified when they are produced by cognitive processes that are highly reliable (Goldman, 2009). Reliabilism is compatible with anti-realism (Beebe, 2007). Traditional received-view foundationalism typically represents a starting point for debate concerning the organization of new knowledge rather than the final word (cf. Kleindorfer, O'Neill, Ganeshan, 1998).

Foundationalist organizing The logic of induction. In terms of the relevance of antirealist foundationalism for new knowledge production in the current era, the emphasis on induction from which scientific knowledge and theories emerge implies collecting lots of data which can be sifted to discover otherwise difficult-to-discern patterns. The prevalence of highspeed computers provides a new impetus for this particular orientation. Computer programs can enable the scanning of data bases for correlations or trends without any realist presuppositions concerning causality or entity existence. The emphasis within any particular domain is on extracting previously unknown knowledge from factual data using quantitative analyses. 
In terms of a logic of organizing, foundationalism would seem to require a small cadre of experts able to interpret correlational patterns in order either to create new theory or to match correlational patterns with existing theory so that new knowledge can be extracted. There is a danger of authoritarianism in this emphasis on the interpretation of patterns in data as has been noted in the debate over evidence-based medicine, where the relevant questions include: who decides what is relevant evidence, and who determines the best interpretation of this collected evidence (Shahar, 1997)? Similarly, in scientific management, the search was for the "one best way," with a relentless pursuit of improvement through empirical measurement, experiment, and statistical display (e.g., the Gantt chart). New knowledge, from this perspective, could be extracted through close attention to work processes rather than from the imaginative promulgation of new theory. In the current era, the reliance on experts continues, but, we suggest, a foundationalist logic of action these days will tend to direct supervision toward large data sets rather than the labor process. Thus, physicists proliferate on Wall Street, bringing their expertise to bear in terms of new algorithms to analyze and profit from trends in financial data (Bernstein, 2008). The consumers of foundationalist-based knowledge are likely to be in the front line of service providers, such as practicing physicians, financial managers, and other professionals.

In terms of the informal structuring of work from a foundationalist perspective, therefore, the work process is likely to be highly centralized around the cadre of experts with specialist training who direct the search for empirical regularities that can serve as the foundation for the production of new knowledge. From a foundationalist perspective, empirical facts remain facts even as the world changes, and even irrespective of whether the facts derive from one disciplinary area or another. Therefore, the cadre of specialists may include people from quite 
different disciplinary backgrounds and representing quite different historical periods of data representation. There may be a mixing of $\mathrm{PhD}$ 's in economics and physics combined together to search for patterns in financial data. To the extent that the focus is on finding patterns in data, rather than on pushing forward the boundaries of disciplines, the common focus on an empirical foundation can provide the basis for cohesion.

This empirical approach can take advantage of knowledge collected over periods of time which is then formalized within a standard set of parameters. The clearest contemporary example of this approach is data mining. The new knowledge discovered through data mining consists of patterns in data that can translate into possible new products that take advantage of hitherto unnoticed correlations. Although data mining typically takes advantage of computer automation and algorithms to generate knowledge discovery, it depends upon a series of judgments including the selection of the knowledge area to be searched, preparing the data set from often heterogenous elements, creating a model that can guide the search process, choosing search algorithms, interpreting results and testing them, and using resulting patterns as the basis for better decision-making or new product development (Goebel \& Gruenwald, 1999). Thus, there would need to be a team of specialists guiding the automated process.

This foundationalist approach to organizing for knowledge generation is, we suggest, exemplified by Synta Pharmaceuticals, a bio-pharmeceutical company focused on the discovery, development, and commercialization of small molecule drugs to treat severe medical conditions. Reversing the standard practice in the industry (which is to start with a theoretical understanding of a disease and then rationally design a customized solution), Synta uses mass screening of chemical compounds in the absence of any theory (Gladwell, 2010: 72). Synta purchases from around the world thousands of chemical compounds, most of which were never designed for 
medical use. These compounds are tested in batches to see if they affect cancer cells. Most compounds have no effect, or prove toxic to all cells. But once in a while, a compound proves efficacious against cancer cells. For example, a compound manufactured at the National Taras Shevchenko University, in Kiev, and purchased by Synta for around ten dollars, proved effective against prostate cancer cells. It was an unusual compound, "homemade, random, and clearly made for no particular purpose" (Gladwell, 2010: 73). Had it not been for the atheoretical, data mining approach employed by Synta, this compound's ability to fight cancer cells may never have been discovered. The foundationalist path to the generation of new knowledge followed by Synta uses a trial-and-error search for new knowledge that makes no a priori assumptions concerning causality yet maximizes the possibility of serendipitous discovery. This example raises the question as to whether computing power has made possible genuinely theory-neutral exploration, in a way that philosophers for decades said could not occur. This new, computer-age foundationalist organizing does not require guiding theory but rather seems to fulfill the empiricist dream of building science from a foundation of empirical data.

In the realm of high-tech companies, Google Inc. is one example of a company that specializes in automated data mining as a core principle of its business. The two founders of the company developed a search engine while PhD students at Stanford University that ranked websites according to the number of connections to other websites. This innovation facilitated data mining in the enormously complex World Wide Web by using information concerning which websites had been "voted" to be the best sources of information by other pages across the web. The company continues to focus on data search through mathematical programming in its development of a range of products and services (Girard, 2009).

\section{Strong Paradigm Perspective}


The other off-diagonal perspective in Figure 1 derives from the work of Thomas Kuhn (1996; originally published in 1962) that combines a belief in the actuality of the physical world with skepticism toward the convergent-realism claim (endorsed by the structural realists) that science progresses to an ever closer approach to truth. We take at face value the assertion by Kuhn that his philosophical position represents an "unregenerate" realism (1979: 415) in the sense that there is a real world out there: "... entirely solid: not in the least respectful of an observer's wishes and desires" (Kuhn, 1990: 10). Kuhn's position is nuanced by the assertion that the members of a successful disciplinary scientific paradigm define for themselves what aspects of reality to attend to, to change, and to adapt.

The paradigmatic community members share education, language, experience, and culture and therefore tend to "see things, process stimuli, in much the same ways" (Kuhn, 1996: 193). The disciplinary matrix that successful scientists share represents reality for them because it selects certain objects for investigation and facilitates the creation of a distinctive social world of scientific endeavor. Kuhn's realism does not commit him to any strong sense that successive scientific theories approach closer to some paradigm-independent truth (even though much empirical content may be preserved when one theoretical paradigm succeeds another -- Kuhn, 1996: 169). One can not step outside of history to evaluate truth claims from a paradigm-free, objective perspective (Kuhn, 1996).

Kuhn's philosophical position is a complex one, but, for our present purposes, we interpret Kuhn as affirming that paradigmatic theories do indeed represent reality although recognizing that successive theories are not assumed to represent closer and closer approximations to "what nature is really like" (Kuhn, 1996: 206). As one explanation of Kuhn's realism noted, "representations arising from attempts to answer different problems need not mesh 
well with each other -- perhaps the world is too complicated for us to get one comprehensive theory" (Hacking, 1981:4). Kuhn modified and clarified his ideas considerably over the years in response to critics' interpretations and misunderstandings (see Weaver \& Gioia, 1994, for a careful discussion of these issues). Kuhn's revisions have been described as putting forward "but a pale reflection of the old, revolutionary Kuhn" (Musgrave, 1971: 296). This revised Kuhn has even been described as "a closet positivist" (Laudan, 1984: 68). Certainly, it is the original ideas that generated much of the discussion in the philosophy of science. In our interpretation of Kuhn, we take into account his later emendations, while agreeing with Weaver and Gioia (1994: 573) that "early works are not necessarily invalidated by later ones."

Strong-paradigm organizing: The logic of exploitation. Strong-paradigm organizing, in our interpretation, is characterized by a unified force of energetic believers who share fundamental assumptions concerning the nature of reality and the practice of research. These believers are likely to be protective of their ideology given that this ideology has been constructed with the utmost difficulty and constitutes the framework within which meaningful activity can be conducted. Paradigm-believers exhibit strong resistance to ideological or cultural change.

Knowledge production from this perspective is, we suggest, likely to be characterized by a relentless focus on the exploitation of existing knowledge bases. Knowledge production consists of such activities as forcing data into existing categories prescribed by the theoretical paradigm, and mopping up remaining corners of unexploited knowledge -- an activity tantamount to puzzle solving (cf. Kuhn, 1996). There is likely to be a tendency to exclude competing views, given that such outside influences can disturb the equanimity of paradigmatic puzzle solving activity. 
Paradigm strong organizing is likely to neglect or ignore persistent anomalies in order to focus on ingenious technological advances and fixes that are compatible with an overall theoretical approach. Such organizing will, we suggest, tend to feature closed boundaries to protect proprietary knowledge through an emphasis on secrecy, patents, copyrights and controls to prevent trade secrets being stolen by rivals. Cohesive networks are one basis for competitive advantage (Coleman, 1990), but brokering across groups is likely to promote careers (Burt, 2004).

Organizations that exemplify a strong paradigm approach to new knowledge production will, we suggest, tend to have strong, distinctive cultures and ideologies that powerfully shape the production of knowledge. For example, within some parts of the computer company described by Kunda (1992), the generation of cutting-edge knowledge involved the formulation and dissemination of ideology, the use of group testimonials and face-to-face control reminiscent of brainwashing techniques, and the invasion of private life by corporate requirements. We might also think of the now-defunct Digital Equipment Company where engineers tended to dismiss the possibility of learning from rivals or the marketplace and tended to cling to the internal, distinctive culture that continued to shape their lives even after they had been dismissed from their jobs (Johnson, 1996). In the realm of current high technology companies involved in distinctive innovation, Apple Computer exhibits strong-paradigm control over knowledge: "... secrecy is one of Apple's signature products....Workers on sensitive projects have to pass through many layers of security. Once at their desks or benches, they are monitored by cameras and they must cover up devices with black cloaks and turn on red warning lights when they are uncovered" (Appleyard, 2009). The consumers of strong-paradigm knowledge production are likely themselves to resemble cult members in their enthusiasm for distinctively-branded 
products that permit their users to differentiate themselves in terms of identity and style (Bhattacharya \& Sen, 2003).

Strong-paradigm organizing is likely to place the emphasis on a supportive community of like-minded scientists, engaged within a common culture, striving to articulate a distinctive vision and solve a set of well-understood problems. Thus, as Figure 2 summarizes, the creation of a scientific paradigm itself is an object to be attained because it represents a wide ranging organizing framework for knowledge production, one which picks out certain problems to be solved while disregarding other problems. A paradigm community shares a disciplinary matrix in terms of procedures, exemplars, formulas and beliefs. Indicators of progress within such a community include success in the solution of outstanding puzzles identified by the paradigmatic community. There is likely to be a strong focus, from this perspective, on new techniques that facilitate the articulation of the paradigm in terms of empirical testing, and that enable solutions to outstanding puzzles.

\section{A Note on Critical Realism}

In choosing characteristic perspectives to populate the four quadrants of Figure 1, we left out some important philosophical approaches that overlap with these four perspectives. But one contemporary philosophy of science approach -- critical realism -- stands out as significantly different from those we have discussed because it focuses on the social world of human interaction rather than the physical world investigated by physics, chemistry and the hard sciences (Bhaskar, 1998). Because of this basic difference, we treat this approach separately rather than including it in the matrix exhibited in Figure 1. The relevance of critical realism for management scholars has been thoroughly discussed elsewhere (e.g., Reed, 2008; Tsang \& Kwan, 1999), so this perspective does not need such an extensive introduction here. Critical 
realism belongs with structural realism in the top left-hand quadrant of Figure 1. But whereas structural realism emphasizes the capture of invariant relations in the form of mathematical equations, critical realism emphasizes that the relationships among entities discovered by social science are likely to be relatively enduring as opposed to completely invariant. The relatively enduring structure of positions in a particular culture, for example, would be considered to have causal power over the attitudes and behaviors of those who temporarily occupy such positions (Archer, 1998).

In focusing on the social world, critical realism emphasizes the stratification of reality. The realm of the real consists of unobservable structures and causal powers, the realm of the actual consists of events and processes in the world, and the realm of the empirical consists of the experiences of human beings (Fairclough, 2005). Thus, critical realism emphasizes that there are underlying structures and forces that are unobservable but that are real in their operations and that are best investigated through ethnographic and historical research (rather than exclusively through quantitative analyses of independent and dependent variables) (Reed, 2008). Critical realism (Archer, Bhaskar, Collier, Wilson \& Norrie, 1998) argues that science, by correcting errors and rejecting false starts, converges to the truth. The critical aspect of this philosophy of science relates to the possibility that an explanatory critique of the ways in which structures of power operate in society can be emancipatory.

New knowledge proceeding from the perspective of critical realism is likely to challenge existing power structures in industry and government. In order to break the mould of current thinking it would be necessary, from this perspective, to tackle the past inheritances put in place by prior thinking that tended to shackle new discovery. Consumers of such knowledge are likely to be social activists, interested in radical changes to the status quo. 
The logic of action associated with critical realism, therefore, is the logic of emancipation. Organizations that exemplify a critical realist approach to new knowledge production will, we suggest, tend to be social action organizations such as Greenpeace that fight in the public sphere to seize rhetorical control over the interpretation of events (Tsoukas, 1999). Not content to just produce new knowledge through its own research laboratories at the University of Exeter, Greenpeace is active in direct campaigns against deforestation, overfishing, commercial whaling, global warming, and nuclear power. Thus, this non-governmental environmental organization attempts to take scientific research and use it to change the attitudes and behaviors of people; and to produce products that provide green alternatives to standard technology.

\section{Combining and Diffusing the Logics}

Given the stark differences between these logics on basic issues of epistemology and ontology, the question arises as to which approach do we consider the best? In writing this paper, for example, which philosophy of science are we implicitly endorsing? As students of organizations, we are persuaded by a garbage-can approach (Cohen, March, \& Olsen, 1972) according to which, in any particular knowledge-producing effort, logics of action can be taken to represent different kinds of solutions available to different types of agents endeavoring to tackle streams of different types of problems. As we have discussed in the paper and summarized in the figures, each philosophical alternative holds different implications for organizing. In terms of our own efforts at knowledge production, we engaged with a pure research effort (i.e., the philosophy of science) generally considered to have little relationship to practical endeavors; we applied this philosophical discourse instrumentally to understanding the production of scientific knowledge; and we have tried to develop a fairly tight paradigm organized around the figures in 
order to exploit the discourses of the philosophy of science. We have not tried in this paper to engage in data mining through the collection of lots of information concerning actual knowledge producing efforts to see empirically what kinds of patterns might be revealed, but recognize that this kind of extensive reviewing can yield valuable discoveries in terms of underlying patterns (e.g., Van de Ven \& Poole, 1995). In short, we anticipate that knowledge-producing efforts will generally feature a variety of logics of action in combination.

Insert Figure 3 about here

For example, Figure 3 outlines a hypothetical knowledge-producing organization that integrates a mix of logics of action. Like other organizations, those focused on knowledge production face technical and environmental uncertainty. To manage this uncertainty, the knowledge producing organization is likely to create certain parts intended specifically to deal with uncertainty, thus allowing certain other parts to carry on the core activities of the organization under conditions of relative certainty (Thompson, 1967). At the technical core of the ideal knowledge-producing organization we envisage a team of structural realists, scientists who completely believe in the mission of discovering the truth about the universe, including the world in which we live. For these scientists, there are few doubts about whether theories represent reality, or whether theories march forward toward greater and greater truth. For example, at Bell Labs, during its illustrious history, the core of its knowledge-producing efforts consisted of the fundamental physics research group that won seven Nobel prizes for discoveries 
including the wave nature of matter and the existence of cosmic microwave background radiation (see Gehani, 2003, for a description of recent events in this organization).

The work of these researchers in discovering new phenomena and solutions to theoretical problems would need, however, to be buffered from environmental fluctuations by a protective belt (cf. Lakatos, 1970) populated by other knowledge workers. The job of the protective belt would be to allow the technical core to operate under conditions approximating certainty by helping the organization to adjust to constraints and contingencies not controlled by the organization. The workers in the protective belt would seek to minimize the knowledgeproducing organization's dependence by maintaining alternatives, actively competing for support and resources through a variety of methods including alliance building, coopting, lobbying, and the use of rhetoric designed to enhance the legitimacy of the organization and its products (Thompson, 1967). We envisage that this protective belt would include instrumentalists who would pragmatically negotiate ways in which pure, blue-sky science could be translated into products and services relevant for problems arising in society (cf. Hilgartner, 2000). We also envisage a group of foundationalists actively scanning data from the environment and matching patterns with ideas emerging from a core group of structural-realist scientists. Further, in this protective belt around the structural realists, we envisage a group of critical realists able to assess the political structures possibly obstructing the emergence of revolutionary ideas, and able to give advice concerning what kinds of products and services might be most expediently introduced in particular sectors, and how these products and services might be characterized. The relative power of these different sets of experts and mediators in the protective belt is likely to change and shift depending upon the kinds of crises provoked by environmental trends (Hickson et al., 1971). 
Skilled mediators are likely to be required to be able to coordinate the flow of resources and knowledge between these various philosophically disparate groups. Philosophical differences concerning such ontological questions as which categories of things are justified can provide arguments against cooperation and change (Suddaby \& Greenwood, 2005). If the knowledge-producing organization must attempt to create something like certainty for its technical core while also retaining flexibility and adaptability to satisfy environmental constraints, we might expect to see a dedicated set of broker-managers charged with smoothing the irregularities stemming from environmental fluctuations while also pushing the technical core to make necessary modifications as external conditions change (Thompson, 1967). We see this whole mélange of scientific and knowledge producing activity immersed in the strong currents of paradigmatic thinking. The ideal organization that we envisage will have been born in the white heat of a Kuhnian revolution that binds the disparate elements together as an insurrectional force opposed to the prior status quo. Thus, like Apple Computer, this hypothetical organization will exploit its technical proficiency in certain specific areas rather than seek to dominate the marketplace with generic products.

At different stages in the development of knowledge, different organizing logics are likely to supplement each other. For example, in the field of synthetic biology, a team of researchers in 2003 successfully created a custom-built package of DNA. The logic of pure science that drove their initial work had to be supplemented, over time, with other logics as the team sought funding and support to translate basic science into successful pharmaceutical drugs. Led by Jay Keasling, a professor of biochemical engineering at the University of California at Berkeley, the team secured $\$ 42.6$ million to use their pure science discovery to combat a problem of concern to the Bill and Melinda Gates foundation: the eradication of malaria. With 
the help of these funds, the team started Amyris Biotechnologies, which then collaborated with the Institute for OneWorld Health, a non-profit drugmaker, and, in 2008, initiated a collaboration with Sanofi-Aventis, a Paris based Pharmaceutical firm to bring anti-malaria drugs to market in 2012 (Specter, 2009). Thus, different organizing logics may prevail during the different stages of knowledge production; and firms may creatively combine different logics over time as they respond to the needs and presses of their evolving institutional environments.

This example illustrates the way in which pure science gets translated into marketplace products through network alliances, and raises the question of how network structure affects the production of knowledge over time. We know that corporate research laboratories, such as Bell Labs, can combine a pure research group with departments devoted to the development of useful products (such as, at Bell Labs, the transistor, the laser, and the UNIX operating system). But how do different parts of the organization relate to each other, and how do relations change over time? What kind of "shadow of the past" is likely to haunt knowledge producers in the present? Network research suggests that the extent to which knowledge-producing groups (such as TV production teams) had cohesive ties within group in the past affects group performance in the future, whereas the extent to which people within the group had ties outside the group in the past does not affect future group performance (Soda, Usai, \& Zaheer, 2004).

Thus, one important question that arises concerns whether cohesion continues to influence what are considered acceptable knowledge directions and standards even as science changes both within the community and outside it. Creativity research (focused on the production of Hollywood musicals) has suggested that, within any given community of producers, the social structure of the community in terms of clustering and connectivity, can significantly affect performance: creative production depends on a fine balance between the 
clustering of like-minded people and the extent of connections across clusters (Uzzi \& Spiro, 2005). The extension and elaboration of these ideas to the production of new scientific knowledge from a philosophy-of-science approach remains to be achieved.

A network approach could also help investigate the ways in which philosophical logics of action spread across communities of organizations (DiMaggio \& Powell, 1983), given evidence that social network connections facilitate a general orientation toward knowledge production irrespective of organizational affiliation (cf. Saxenian, 1994). The diffusion of a particular way of thinking about and doing science can demonstrate a social-movement type fervor (Davis, McAdam, Scott, \& Zald, 2005), a "mob psychology" or bandwagon effect (Abrahamson \& Rosenkopf, 1993; Rogers \& Kincaid, 1981), that some have argued detracts from the rationality of scientific progress (Lakatos, 1970: 140). There would seem to be considerable difference of opinion concerning whether, as Lakatos (1970) claims, such social-movement fervor results in only temporary aberrations from the rational progression of scientific advances, or whether rational reconstructions of knowledge progression (of the kind championed by Lakatos, 1970) ignore the irrationality of so-called scientific progress that is characterized by shifts between incommensurable worldviews (e.g., Feyerabend, 1977). If knowledge production is selfcorrecting in terms of its historical evolution (a view that is compatible with Lakatos's, 1970, perspective), then understanding how a-logic-of-action bandwagon diverts resources from one research program to another is still important in helping explain why discovery and invention might be, in some cases, delayed. If, however, knowledge production is path-dependent such that if one research program is supported rather than another then the history of knowledge production becomes quite different (a view put forward by Noble, 1977), then understanding the 
spread of logics of action used to justify resource distribution within and across knowledgeproducing communities becomes a high priority task for scholars.

As logics of organizing spread across organizational fields (i.e., communities of organizations engaged in related activities -- DiMaggio \& Powell, 1983) to provide shared schema, practices, and justifications to heterogeneous groups of organizations engaged in knowledge alliances and product development, this is likely to facilitate collaboration and the formation of alliances. The field of biotechnology, for example, originated in university labs in the 1970s (Zucker \& Darby, 1996), saw the emergence of numerous small science-based firms in the 1980s, and has been bringing a number of new medicines to market since the 1990s. Because no single organization controls all the competencies required to develop and successfully bring a drug to market, organizations in this field tend to be embedded in numerous alliances with other organizations (Powell, Koput, \& Smith-Doerr, 1996; Powell, White, Koput, and Owen-Smith, 2005).

When scientific results have to be transferred from one institutional context to another, they routinely have to be reshaped and recast (Hilgartner, 1990). Research universities continue to pursue blue sky research, whereas industry tends to be the home of more pragmatic, problemsolving work. If academia and industry seek to collaborate, will basic differences in philosophically-based logics of organizing handicap interactions? Is there a role in such collaborations for philosophical brokers trained in the different philosophical perspectives, and able to see where fruitful divisions of labor might be appropriate? Organizational theory has emphasized the benefits of brokerage (e.g., Burt, 1992). However, brokerage, to the extent that it requires individuals to occupy themselves in different and disconnected fields, can pose threats to the reputation of individuals in the eyes of colleagues (cf. Podolny, 2001), and can, indeed, 
lead to the broker being perceived as a parasite who feeds on the weakness of others (Serres, 1980). In breaching academic boundaries, one "risks the chance of slipping in between fields and finding oneself doing work that no one finds relevant" (Pernu, 2008: 32). A better understanding of the tactics employed in successful brokerage between knowledge producing entities organized around different philosophical logics is a topic for future research.

\section{DISCUSSION}

If the philosophy of science is underutilized in discussions of the organization and production of new knowledge (Grandori \& Kogut, 2002: 224) this is, perhaps, evidence of the fragmentation of knowledge into sub-genres in the modern Academy in which professional philosophy and organizational studies are separate silos of specialized thinking. In bringing renewed attention to philosophy of science discourse, the aim has been to undertake a creative synthesis in order to open up new possibilities for theorizing and research concerning the production of scientific knowledge.

The philosophy of science, besides providing a distinctive menu of possibilities for management research (Kleindorfer, O'Neill, \& Ganeshan, 1998) also has the potential to model the rational production of knowledge in organizations (Kilduff \& Mehra, 2008). In this paper, we have suggested a set of ideal-type logics of action derived from the philosophy of science including the logic of pure research (which emphasizes the enduring structural content of scientific theory and justifies large groups of specialists communally working on massive projects); the logic of induction (which emphasizes the investigation and interpretation by a cadre of experts of patterns inherent in empirical data); the logic of problem-solving (which emphasizes practical action and an open community of experts with backgrounds that cross disciplines); strong-paradigm logic (which emphasizes the relentless articulation of procedures to 
solve outstanding puzzles within paradigmatic communities); and the logic of emancipation (which emphasizes subversive challenges to prevailing knowledge assumptions).

Our paper has focused on the organizing process considered as a stream of knowledge (von Krogh, Roos, \& Slocum, 1994), a process of transformation by which background assumptions shared by organizational participants not only guide the interpretation of events (cf. March \& Simon, 1958) but also facilitate the enactment of internal and external environments (Weick, 1979) within structures of constraint and control that are themselves reproduced by strategic actors (Giddens, 1984). We have argued that knowledge production is shaped by underlying assumptions rooted in the philosophy of science that provide different logics for organizing. Assumptions concerning ontology and epistemology, often adopted during the formal scientific training process, are likely to affect the kind of research scientific knowledge workers pursue, the kind of new knowledge that they produce, and the way they organize to achieve their objectives. This is clear enough in the case of university researchers (See CroutherHeyck, 2005, for the influence of logical positivism on Herbert Simon; and Holton, 1993, for the influence of Mach's philosophy on B.F. Skinner.), but we theorize that knowledge workers in other settings are similarly influenced by the discourses of the philosophy of science.

We have argued that discourses in the philosophy of science shape the logics of organizing adopted by knowledge producing organizations. But this is to assume that causality operates in only one direction. It is also possible that researchers interested in a certain type of knowledge production may adopt pragmatically a distinctive discourse associated with a philosophy of science in order to justify actions and extract resources from the environment. Further, we suggest that philosophical assumptions are particularly likely to be invoked during conflicts over funding, status, or credit for new knowledge production. Even though we have 
suggested that physicists at the Large Hadron Collider are likely to have absorbed a structural realist orientation during their training, it is also likely that researchers involved in much smaller projects (e.g., researchers in a small biochemistry lab) faced with having to justify their work may resort to a structural realist logic of action. Scientists may use different philosophical views in order to legitimize and delegitimize arguments in the eyes of various audiences. For example, in a dispute over plate tectonics (Le Grand, 1986), "some portrayed themselves as more concerned with fidelity to data and thus more empiricist; some portrayed themselves as making their claims more precisely falsifiable; and some took the risky strategy of allying themselves with a Kuhnian picture of science" (Sismondo, 2010: 127). How knowledge producers embroiled in disputes convince or fail to convince audiences of the merits of their views is a question that deserves the attention of organizational researchers.

Understanding the philosophical underpinnings of science logics and their implications for organizing knowledge production may be especially relevant in the current era of changes in science. In the changing landscape of scientific knowledge production, research groups in universities are considered "quasi firms" that have frequent knowledge transactions with industry (Kedl, 2009: 229; Oliver, 2008: 195). Looking around the intellectual landscape one sees a market "of independent epistemic monopolies producing vastly different products" (KnorrCetina, 1999: 4). This erosion of the demarcation between universities and other knowledge producing organizations and the resultant emergence of hybrid organizational forms (Nowotny, Scott, \& Gibbons, 2001) open opportunities for institutional entrepreneurs (cf. DiMaggio, 1988) to employ a range of logics of action given the contemporary lack of clarity concerning what constitutes a scientific contribution (Ziman, 1996). Some eminent scientists, for example, have been accused of launching campaigns that employed "disinformation of various sorts coupled 
with an enduring and disgraceful willingness to stick to discredited arguments" to influence legislation on a host of issues, from the depletion of the ozone layer to the death of forests through acid rain (Economist, 2010: 86; Oreskes \& Conway, 2010). The entrepreneurial manipulation of institutional logics of action takes place within a broader environment in which government regulators and the public are important stakeholders (cf. Misangyi, Weaver, \& Elms, 2008).

We call for greater attention to the use and misuse of logics of action by organizational representatives in debates concerning science policy, funding, and legislation. The role of professional philosophers of science as experts in providing policy advice to organizational actors could profitably be explored, following the example of work that has examined the role of science experts in policy debates (Hilgartner, 2000). Indeed, there are several themes within the science and technology studies field that could be explored from the perspective put forward in this paper. These include: how the norms of scientific rationality may be determined to further the class interests of professionals (e.g., Shapin, 1975); how the popularization of science can affect the process of knowledge production (e.g., Hilgartner, 1990; Collins \& Pinch, 1993); how scientific phenomena themselves can be socially constructed (e.g., Knorr Cetina, 1999); and how resources are enrolled in knowledge networks that combine patrons, laboratory equipment, established knowledge, and other heterogeneous elements (e.g., Latour, 1987).

We also call attention to the importance of the "strong programme" in science and technology studies (Bloor, 1991), particularly the focus on the ways in which institutionalized beliefs (such as scientific logics of action) become adopted by rational people even if, to outsiders, these beliefs are disputed, or are seen as less than rational in their operations or consequences (cf. Suddaby \& Greenwood, 2005). Researchers, according to this perspective, 
need to be self-reflective concerning how they privilege one type of science over another. One of the principles enunciated by the strong programme is that true and false beliefs should be explained by the same theory (Bloor, 1991: 7). This principle suggests that the philosophy-ofscience-based theory that we have articulated should be developed to be able to explain knowledge production considered by some to be pseudoscientific (e.g., advances in homeopathic medicine).

We have investigated in this paper a set of relatively abstract discourses concerning the progress of science, and have suggested that these discourses are relevant to the production of new knowledge across a range of scientific organizations that include but are not restricted to universities. The discourses of the philosophy of science, we have suggested, can be relevant not just for understanding how trained scientists produce new knowledge, but also how the many other people designated in organizations as "knowledge workers" produce new knowledge. If this essay has one overarching conclusion it is that the philosophy of science can promote alternative constructions of how knowledge can be produced, and these alternative constructions can facilitate organizational experiments across otherwise entrenched knowledge silos. 


\section{REFERENCES}

Abrahamson, E., \& Rosenkopf, L. 1993. Institutional and competitive bandwagons: Using mathematical modeling as a tool to explore innovation diffusion. Academy of Management Review, 18: 487-517.

Appleyard, B. 2009. Steve Jobs: The man who polished Apple. Sunday Times, August 16. http://technology.timesonline.co.uk/tol/news/tech_and_web/article6797859.ece?token=nu 11\&offset $=12 \&$ page $=2$

Archer, M. 1998. Introduction: Realism in the social sciences. In M. Archer, R. Bhaskar, A. Collier, T. Lawson, \& A. Norrie (Eds.), Critical realism: Essential readings: 189-205. New York: Routledge.

Archer, M., Bhaskar, R., Collier, A., Lawson, T., \& Norrie, A. (Eds.). 1998. Critical realism: Essential readings. New York: Routledge.

Ayer, A. J. 1952. Language, truth and logic. Mineola, NY: Dover.

Baron, J. N., Hannan, M. T., \& Burton, M. D. 1999. Building the iron cage: Determinants of managerial intensity in the early years of organizations. American Sociological Review, 64: 527-547.

Beebe, J. 2007. Reliabilism and antirealist theories of truth. Erkenntnis, 66: 375-391.

Bernstein, J. 2008. Physicists on Wall Street and other essays on science and society. New York: Springer.

Bhaskar, R. 1998. General introduction. In M. Archer, R. Bhaskar, A. Collier, T. Lawson, \& A. Norrie (Eds.), Critical realism: Essential readings: ix-xxiv. New York: Routledge. 
Bhattacharya, C. B., \& Sen, S. 2003. Consumer-company identification: A framework for understanding consumers' relationships with companies. Journal of Marketing, 67: 7688.

Bloor, D. 1991. Knowledge and social imagery (2nd ed.). Chicago: University of Chicago Press. Bortolotti, L. 2008. An introduction to the philosophy of science. Malden, MA: Polity.

Burt, R. 1992. Structural holes. Cambridge, MA: Harvard University Press.

Burt, R. S. 2004. Structural holes and good ideas. American Journal of Sociology, 110: 349399.

Camilli, R., Reddy, C. M., Yoerger, D. R., Van Mooy, B. A. S., Jakuba, M. V., Kinsey, J. C., McIntyre, C. P., Sylva, S. P., Maloney, J. V. 2010. Tracking hydrocarbon plume transport and biodegration at Deepwater Horizon. Science, 330: 201-204.

Carnap, R. (1928). Der Logische Aufbau der Welt. Berlin, Germany: Weltkreis-Verlag.

Cartwright, N. 1983. How the laws of physics lie. Oxford, UK: Clarendon Press.

Chalmers, A. F. 1999. What is this thing called science? (3rd ed.). Indianapolis, IN: Hackett.

Chapman, M. 2007. 40 days and 40 nights. New York: Collins.

Chesbrough, H. 2002. Graceful exits and missed opportunities: Xerox's management of its technology spin-off organizations. Business History Review, 76: 803-837.

Cohen, M. D., March, J. G., \& J. P. Olsen. 1972. A garbage can model of organizational choice. Administrative Science Quarterly, 17: 1-25.

Coleman, J. S. 1990. Foundations of social theory. Boston: Belknap Press.

Collins, H., \& T. Pinch. 1993. The Golem: What everyone should know about science. Cambridge University Press.

Crane, T., \& Mellor, D. H. 1990. There is no question of physicalism. Mind, 99: 185-206. 
Creath, R. 1985. Taking theories seriously. Synthese, 62: 317-345.

Crouther-Heyck, H. 2005. Herbert A. Simon: The bounds of reason in modern America. Baltimore: Johns Hopkins University Press.

Davis, G., McAdam, D., Scott, R. W., \& Zald, M. (Eds.). 2005. Social movements and organization theory. New York: Cambridge University Press.

Dewey, J. 1903. Studies in logical theory. Chicago: University of Chicago Press.

DiMaggio, P. 1988. Interest and agency in institutional theory. In L.G. Zucker (Ed.), Institutional patterns and organizations: 3-21. Cambridge, MA: Ballinger.

DiMaggio, P. \& W. W. Powell. 1983. The iron cage revisited. Institutional isomorphism and collective rationality in organizational fields. American Sociological Review, 48: 147160.

Duhem, P. 1969. To save the phenomena. An essay on the idea of physical theory from Plato to Galileo. Chicago: University of Chicago Press.

Dunn, M. B., \& Jones, C. 2010. Institutional logics \& institutional pluralism: The contestation of care \& science logics in medical education, 1967-2005. Administrative Science Quarterly, 55: 114-145.

Economist. 2010. All guns blazing: A question of dodgy science. June 17, 2010.

Eddington, A. 1939. The philosophy of physical science. Cambridge, UK: Cambridge University Press.

Fairclough, N. 2005. Peripheral vision: Discourse analysis in organization studies: The case for critical realism. Organization Studies, 26: 915-939.

Feyerabend, P. 1975. Against method: Outline of an anarchistic theory of knowledge. London: New Left Books. 
Feyerabend, P. 1977. Changing patterns of reconstruction. British Journal for the Philosophy of Science, 28: 351-369.

French, S., \& Ladyman, J. 2003. Remodelling structural realism: Quantum physics and the metaphysics of structure. Synthese, 136: 31-56.

Friedland, R., \& Alford, R. 1991. Bringing society back in: Symbols, practices \& institutional contradictions. In W. W. Powell \& P. J. DiMaggio (Eds.), The new institutionalism in organizational analysis: 232-263. Chicago: University of Chicago Press.

Friedman, M. 1953. Essays in positive economics. Chicago: University of Chicago Press.

Friedson, E. 1970. Professional dominance: The social structure of medical care. New York: Atherton Press.

Friedson, E. 2001. Professionalism: The third logic. Chicago: University of Chicago Press.

Fuller, S. 2003. Kuhn vs. Popper: The struggle for the soul of science. Cambridge, UK: Icon.

Gehani, N. 2003. Bell Labs: Life in the crown jewel. Summit, NJ: Silicon Press.

Gibbons, M., Limoges, C., Nowotny, H., Schwartzman, S., Scott, P., \& Trow, M. (Eds.). 1994. The new production of knowledge: The dynamics of science and research in contemporary societies. London: Sage.

Giddens, A. 1984. The constitution of society. Berkeley, CA: University of California Press.

Girard, B. 2009. The Google way: How one company is revolutionizing management as we know it. San Francisco, CA: No Starch Press.

Gladwell, M. 2010. The treatment: Why is it so difficult to develop drugs for cancer? The New Yorker, May 17: 69.

Goebel, M., \& Gruenwald, L. 1999. A survey of data mining and knowledge discovery tools. ACM SIGKDD Explorations Newsletter, 1 (1): 20-33. 
Godfrey-Smith, P. 2003. Theory and reality: An introduction to the philosophy of science. Chicago: University of Chicago Press.

Goldman, A. 2009. Reliabilism. Stanford Encyclopedia of Philosophy. http://plato.stanford.edu/entries/reliabilism/

Grandin, K., Wormbs, N., \& Widmalm, S. (Eds.). 2005. The science-industry nexus: History, policy, implications. Sagamore Beach, MA: Science History Publications.

Grandori, A., \& Kogut, B. 2002. Dialogue on organization and knowledge. Organization Science, 13: 224-231.

Greenwood, R., Suddaby R., \& Hinings, C. R. 2002. Theorizing change: The role of professional associations in the transformation of institutionalized fields. Academy of Management Journal, 45: 58-80.

Hacking, I. 1981. Introduction. In I. Hacking (Ed.), Scientific revolutions: 1-5. Oxford, UK: Oxford University Press.

Hanson, N. R. 1958. Patterns of discovery: An inquiry into the conceptual foundations of science. Cambridge, UK: Cambridge University Press.

Hardy, C., \& Maguire, S. 2008. Institutional entrepreneurship. In R. Greenwood, C. Oliver, K. Sahlin, \& R. Suddaby (Eds.), The Sage handbook of organizational institutionalism: 198-217. London, UK: Sage.

Hargadon, A. B., \& Douglas, Y. 2001. When innovations meet institutions: Edison and the design of electric light. Administrative Science Quarterly, 46: 476-501.

Hessels, L. K., \& van Lente, H. 2008. Re-thinking new knowledge production: A literature review and a research agenda. Research Policy, 37: 740-760. 
Hickson, D. J., Hinings, C. R., Lee, C. A., Schneck, R. E., \& Pennings, J. M. 1971. A strategic contingencies' theory of intraorganizational power. Administrative Science Quarterly, 16: $216-229$.

Hilgartner, S. 1990. The dominant view of popularization: Conceptual problems, political uses. Social Studies of Science, 20: 519-539.

Hilgartner, S. 2000. Science on stage: Expert advice as public drama. Stanford, CA: Stanford University Press.

Holton, G. 1993. Science and anti-science. Cambridge, MA: Harvard University Press.

Horwich, P. 1991. On the nature and norms of theoretical commitment. Philosophy of Science, 58: $1-14$.

Johnson, K. 1996. Divorced from the job, still wedded to the culture. New York Times, June 16: F11.

Kedl, R. M. 2009. Revolving doors: from academia to industry and back again. Nature Immunology, 10 (3): 227-229.

Kilduff, M., \& Mehra, A. 2008. Philosophy as core competence. In D. Barry \& H. Hansen (Eds.), The Sage handbook of new approaches in management and organization: 7981. London: Sage.

Kleindorfer, G. B., O’Neill, L., \& Ganeshan, R. 1998. Validation in simulation: various positions in the philosophy of science. Management Science, 8: 1087-1099.

Knorr-Cetina, K. 1999. Epistemic cultures: How the sciences make knowledge. Cambridge, MA: Harvard University Press.

Kuhn, T. S. 1979. Metaphor in science. In A. Ortony (Ed.), Metaphor and thought: 409-419. Cambridge, UK: Cambridge University Press. 
Kuhn, T. S. 1990. The road since structure. PSA: Proceedings of the Biennial Meeting of the Philosophy of Science Association, 2: 3-13.

Kuhn, T. S. 1996. The structure of scientific revolutions (3rd ed.). Chicago: University of Chicago Press.

Kunda, G. 1992. Engineering culture: Control and commitment in a high-tech corporation. Philadelphia: Temple University Press.

Ladyman, J. 1998. What is structural realism? Studies in History and Philosophy of Science, 29: 409-424.

Lakatos, I. 1970. Falsification and the methodology of scientific research programs. In I. Lakatos \& A. Musgrave (Eds.), Criticism and the growth of knowledge: 91-196. Cambridge, UK: Cambridge University Press.

Latour, B. 1987. Science in action: How to follow scientists and engineers through society. Cambridge, MA: Harvard University Press.

Laudan, L. 1977. Progress and its problems: Towards a theory of scientific growth. London: Routledge \& Kegan Paul.

Laudan, L. 1981. A confutation of convergent realism. Philosophy of Science, 48: 19-49.

Laudan, L. 1984. Science and values: The aims of science and their role in scientific debate. Berkeley: University of California Press.

Laudan, L. 1990. Science and relativism: Some key controversies in the philosophy of science. Chicago: University of Chicago Press.

Le Grand, H. E. 1986. Steady as a rock: Methodology \& moving continents. In J. Schuster, R. Yeo (Eds.), The politics and rhetoric of scientific method: Historical studies: 97-138. Dordrecht, Netherlands: Reidel,. 
Lounsbury, M. 2007. A tale of two cities: Competing logics \& practice variation in the professionalizing of mutual funds. Academy of Management Journal, 50: 289-307.

McKelvey, B. 2002. Model-centered organization science epistemology. In J. A. C. Baum (Ed.), The Blackwell companion to organizations: 752-780. Oxford, UK: Blackwell.

March, J. G., \& Simon, H. A. 1958. Organizations. New York: Wiley.

Maxwell, N. 2010. Scientists should stop deceiving us. http://www.guardian.co.uk/commentisfree/2010/mar/12/philosopy-of-science-climatechange

Merali, Z. 2010. The large human collider. Nature, 464: 482-484.

Misangyi, V. F., Weaver, G. R., \& Elms, H. 2008. Ending corruption: The interplay among institutional logics, resources, and institutional entrepreneurs. Academy of Management Review, 33: 750-770.

Musgrave, A., 1971, Kuhn's Second Thoughts. British Journal of the Philosophy of Science, 22: 287-97.

Noble, D. F. 1977. America by design: Science, technology, and the rise of corporate capitalism. New York: Knopf.

Nowotny, H., Scott, P., \& Gibbons, M. 2001. Re-thinking science: Knowledge and the public in an age of uncertainty. Cambridge, UK: Polity Press.

Okasha, S. 2002. Philosophy of science: A very short introduction. Oxford, UK: Oxford University Press.

Oliver, A. L. 2008. University-based biotechnology spin-offs. In H. Patzelt \& T. Brenner (eds.), Handbook of Bioentrepreneurship: 193-210. New York: Springer. 
Oreskes, N., \& Conway, E. 2010. Merchants of doubt: How a handful of scientists obscured the truth on issues from tobacco smoke to global warming. Bloomsbury Press.

Overbye, D. 2002. Are they a) geniuses or b) jokers? French physicists' cosmic theory creates a Big Bang of its own. New York Times, November 9: B7.

Pernu, T. K. 2008. Philosophy and the front line of science. The Quarterly Review of Biology, 83: 29-36.

Podolny, J. M. 2001. Networks as the pipes and prisms of the market. American Journal of Sociology, 33-60.

Poincaré, H. 1905. Science and hypothesis. New York: Dover.

Popper, K. 1963. Conjectures and refutations. London: Routledge \& Kegan Paul.

Popper, K. 1970. Normal science and its dangers. In I. Lakatos \& A. Musgrave (Eds.), Criticism and the growth of knowledge: 51-58. Cambridge, UK: Cambridge University Press.

Powell, W. W., Koput, K. W., \& Smith-Doerr, L. 1996. Interorganizational collaboration and the locus of innovation: Networks of learning in biotechnology. Administrative Science Quarterly, 41: 116-145.

Powell, W. W., Koput, K. W., White, D. R., \& Owen-Smith, J. 2005. Network dynamics \& field evolution: The growth of interorganizational collaboration in the life sciences. American Journal of Sociology, 110: 1132-1205.

Psillos, S. 1995. Is structural realism the best of both worlds? Dialectica, 49: 15-46.

Psillos, S. 1999. Scientific realism: How science tracks truth. New York: Routledge.

Putnam, H. 1962. What theories are not. In E. Nagel (ed.), Logic, methodology and philosophy of science: $240-251$. Stanford, CA: Stanford University Press.

Putnam, H. 1975. What is 'realism'? Proceedings of the Aristotelian Society, 76: 177-194. 
Putnam, H. 1987. The many faces of realism. LaSalle, IL: Open Court.

Ray, C. 2000a. Einstein. In W. H. Newton-Smith (ed.), A companion to the philosophy of science: 102-107 Malden, MA: Blackwell.

Ray, C. 2000b. Logical positivism. In W. H. Newton-Smith (ed.), A companion to the philosophy of science: $243-251$. Malden, MA: Blackwell.

Rao, H., Monin, P., \& Durand, R. 2003. Institutional change in Toque Ville: Nouvelle cuisine as an identity movement in French gastronomy. American Journal of Sociology, 108: 795843.

Raymond, E. S. 1999. The cathedral and the bazaar. Beijing, China: O'Reilly.

Reed, M. 2008. Exploring Plato's cave: Critical realism in the study of organization and management. In D. Barry \& H. Hansen (eds.), The Sage handbook of new approaches in management and organization: 68-78. London: Sage.

Reichenbach, H. 1938. Experience and prediction. Chicago: University of Chicago Press.

Rogers, E. M. \& Kincaid, D. L. 1981. Communication networks: Toward a new paradigm for research. New York: Free Press.

Saxenian, A. L. 1994. Regional advantage: Culture and competition in Silicon Valley and Route 128. Cambridge, MA: Harvard University Press.

Serres, M. 1980. La parasite. Paris: Grasset.

Shahar, E. 1997. A Popperian perspective of the term 'evidence-based medicine.' Journal of Evaluation in Clinical Practice, 3 (2): 109-116.

Shapin, S. 1975. Phrenological knowledge and the social structure of early nineteenth-century Edinburgh. Annals of Science, 32: 219-243.

Sismondo, S. 2010. An introduction to science \& technology studies, 2nd ed. Wiley-Blackwell. 
Sleeper, L. C. 1986. The necessity of pragmatism: John Dewey's conception of philosophy. New Haven, CT: Yale University Press.

Soda, G., Usai, A., \& Zaheer, A. 2004. Network memory: The influence of past and current networks on performance. Academy of Management Journal, 47: 893-906.

Specter, M. 2009. A life of its own: Where will synthetic biology lead us? The New Yorker, September 28, 2009.

Stein, H. 1989. Yes, but... some skeptical remarks on realism and anti-realism. Dialectica, 43: 4765.

Suddaby, R., \& Greenwood, R. 2005. Rhetorical strategies of legitimacy. Administrative Science Quarterly, 50: 35-67.

Suppe, F. 1972. What's wrong with the received view on the structure of scientific theories? Philosophy of Science, 39: 1-19.

Suppe, F. 2000. Understanding scientific theories: An assessment of developments, 1969-1998. Philosophy of Science, 67: S102-S115.

Taleb, N. 2007. The black swan: The impact of the highly improbable. New York: Random House.

Tankersley, J. 2010. Engineering a solution to the oil spill. Los Angeles Times, May 21, 2010.

Thomas, W. I., \& Thomas, D. S. 1928. The child in America: Behavior problems and programs. New York: Knopf, 1928.

Thompson, J. 1967. Organizations in action. New York: McGraw-Hill.

Thornton, P. H. \& Ocasio, W. 2008. Institutional logics. In R. Greenwood, C. Oliver, K. Sahlin, \& R. Suddaby (eds.), The Sage handbook of organizational institutionalism: 99-129. London: Sage. 
Tsang, E. \& Kwan, K. 1999. Replication and theory development in organizational science: A critical realist perspective. Academy of Management Review, 24: 759-780.

Tsoukas, H. 1999. David and Goliath in the risk society: Making sense of the conflict between Shell and Greenpeace in the North Sea. Organization, 6: 499-528.

Uebel, T. E. 1996. Anti-foundationalism and the Vienna Circle's revolution in philosophy. British Journal for the Philosophy of Science, 47: 415-440.

Uzzi, B., \& Spiro, J. 2005. Collaboration and creativity: The small world problem. American Journal of Sociology, 111: 447-504.

Van de Ven, A. H. \& Poole, M. S. 1995. Explaining development and change in organizations. Academy of Management Review, 20: 510-540.

Van Maanen, J. \& Barley, S. 1984. Occupational communities: Culture \& control in organizations. Research in Organizational Behavior, 6: 287-365.

Van Maanen, J. \& Schein, E. 1979. Toward a theory of organizational socialization. Research in Organizational Behavior, 1: 209-264.

von Hippel, E. 2005. Democratizing innovation, Cambridge, MA: MIT Press.

von Krogh, G., Roos, J., \& Slocum, K. 1994. An essay on corporate epistemology. Strategic Management Journal, 15: 53-71.

Watson, J. D. 1968. The double helix: A personal account of the discovery of the structure of DNA. New York: Atheneum.

Weaver, G. R., \& Gioia, D. A. 1994. Paradigms lost: Incommensurability vs. structurationist inquiry. Organization Studies, 15: 565-589.

Weick, K. E. 1979. The social psychology of organizing. New York: Random House. 
Wolters, G. 2000. Mach. In W.H. Newton-Smith (ed.), A companion to the philosophy of science: 252-256. Malden, MA: Blackwell.

Worrall, J. 1989. Structural realism: The best of both worlds. Dialectica, 43: 99-124.

Ziman, J. 1996. "Postacademic science": Constructing knowledge with networks and norms. Science Studies, 1: 67-80.

Zucker, L. G. 1977. Role of institutionalization in cultural persistence. American Sociological Review, 42: 726-743.

Zucker, L., \& Darby, M. R. 1996. Star scientists and institutional transformation: Patterns of invention \& innovation in the formation of the biotechnology industry. Proceedings of the National Academy of Sciences, 93: 12709-12716. 


\section{FIGURE 1}

\section{Matrix of Philosophy of Science Approaches and Associated Logics of Action}

\section{Epistemology}

Science gets closer and closer to the truth?

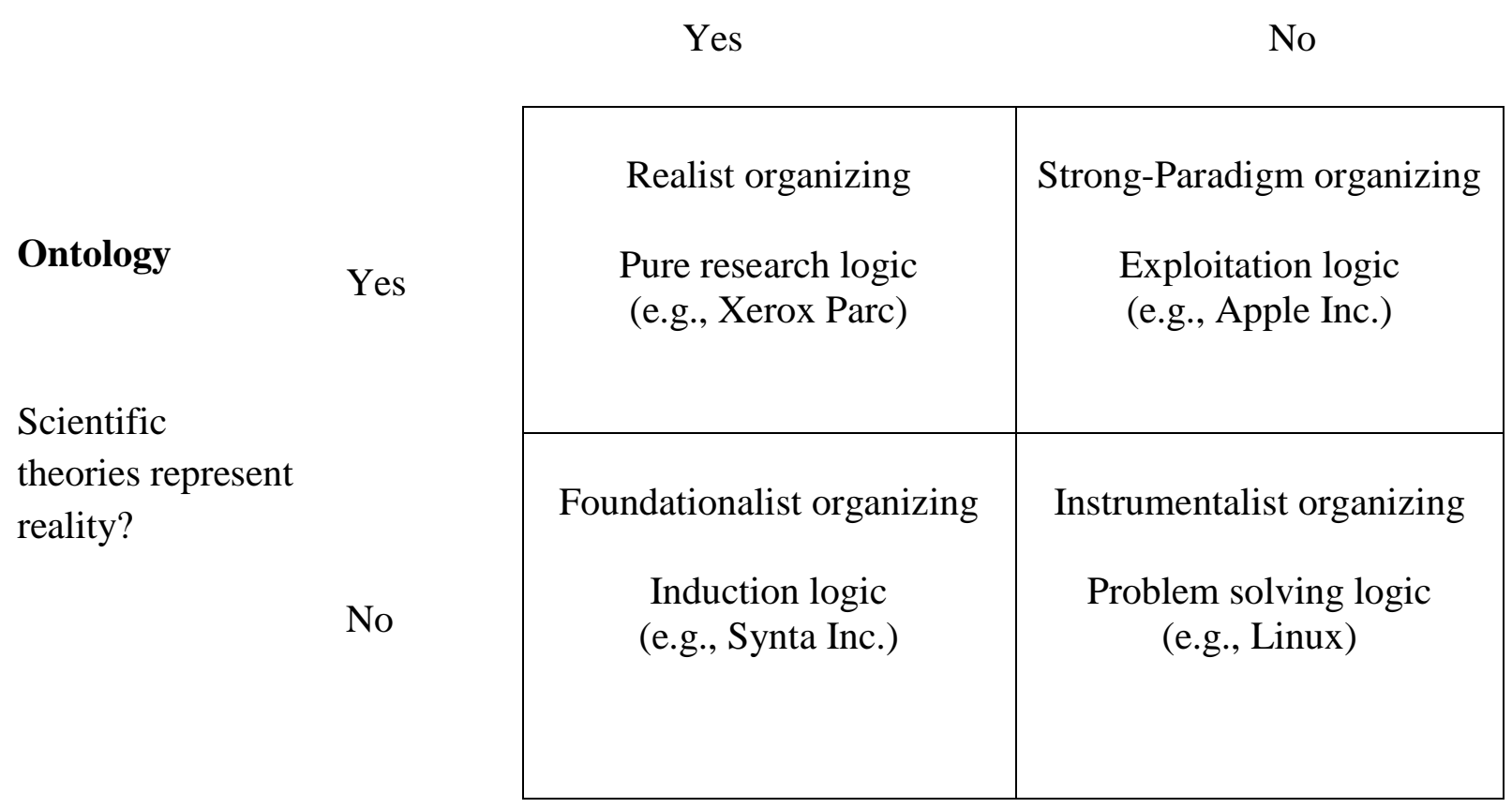


FIGURE 2

\section{Implications of Philosophies of Science for Organizing}

Characteristic goal, and logic of action?

Example of type of knowledge produced?

Indicators of progress?

Characteristic method?

Illustrative organizing?

Organizational Examples?

\section{Structural realist}

Foundationalist

Instrumentalist

Strong paradigm

Critical realist

\begin{tabular}{|c|c|c|c|c|}
\hline $\begin{array}{l}\text { Discover } \\
\text { fundamental } \\
\text { structure of the } \\
\text { universe through } \\
\text { pure research }\end{array}$ & $\begin{array}{l}\text { Find hidden } \\
\text { patterns in data } \\
\text { through induction }\end{array}$ & $\begin{array}{l}\text { Truth-independent } \\
\text { problem solving }\end{array}$ & $\begin{array}{l}\text { Create scientific } \\
\text { paradigm and exploit } \\
\text { its implications }\end{array}$ & $\begin{array}{l}\text { Emancipate people } \\
\text { from prevailing } \\
\text { structures of power } \\
\text { and oppression }\end{array}$ \\
\hline $\begin{array}{l}\text { Scientific } \\
\text { breakthroughs, } \\
\text { irrespective of } \\
\text { commercial } \\
\text { implications }\end{array}$ & $\begin{array}{l}\text { Serendipitous } \\
\text { discovery of } \\
\text { patterns in data } \\
\text { from which new } \\
\text { theory can be } \\
\text { formulated }\end{array}$ & $\begin{array}{l}\text { Pragmatic solutions } \\
\text { to theoretically- } \\
\text { defined problems }\end{array}$ & $\begin{array}{l}\text { Knowledge and } \\
\text { products consistent } \\
\text { with the overarching } \\
\text { culture of } \\
\text { paradigmatic } \\
\text { community }\end{array}$ & $\begin{array}{l}\text { Exposés of powerful } \\
\text { actors' policies and } \\
\text { actions }\end{array}$ \\
\hline $\begin{array}{l}\text { Causal } \\
\text { expression of } \\
\text { relationships } \\
\text { among } \\
\text { theoretical terms; } \\
\text { verification of } \\
\text { causal relations } \\
\text { among terms }\end{array}$ & $\begin{array}{l}\text { Unexpected but } \\
\text { replicable } \\
\text { correlations } \\
\text { indicative of new } \\
\text { discoveries; } \\
\text { counterintuitive } \\
\text { derivations from } \\
\text { first principles }\end{array}$ & $\begin{array}{l}\text { Greater number of } \\
\text { important problems } \\
\text { solved }\end{array}$ & $\begin{array}{l}\text { Using paradigm- } \\
\text { defined facts to solve } \\
\text { puzzles; articulation } \\
\text { of the paradigm } \\
\text { through empirical } \\
\text { work }\end{array}$ & $\begin{array}{l}\text { Challenge prevailing } \\
\text { power structures, and } \\
\text { re-imagine possible } \\
\text { meanings attached to } \\
\text { current practices }\end{array}$ \\
\hline $\begin{array}{l}\text { Mathematical } \\
\text { model building }\end{array}$ & Data mining & $\begin{array}{l}\text { Those that are } \\
\text { considered } \\
\text { historically and } \\
\text { socially legitimate }\end{array}$ & $\begin{array}{l}\text { Defined by } \\
\text { methodological } \\
\text { exemplars within the } \\
\text { paradigm }\end{array}$ & $\begin{array}{l}\text { Anthropology of } \\
\text { everyday life }\end{array}$ \\
\hline $\begin{array}{l}\text { Self-governing } \\
\text { community }\end{array}$ & Cadre of experts & $\begin{array}{l}\text { Cross-field, focused } \\
\text { collaboration }\end{array}$ & $\begin{array}{l}\text { Fortress-like } \\
\text { organization }\end{array}$ & Subversive team \\
\hline $\begin{array}{l}\text { Large Hadron } \\
\text { Collider; } \\
\text { Xerox Parc }\end{array}$ & $\begin{array}{l}\text { Synta } \\
\text { Pharmaceuticals } \\
\text { Corp.; } \\
\text { Google Inc. }\end{array}$ & $\begin{array}{l}\text { Team working to } \\
\text { cap Gulf oil spill; } \\
\text { Linux }\end{array}$ & $\begin{array}{l}\text { Digital Equipment } \\
\text { Company } \\
\text { Apple Computer }\end{array}$ & Greenpeace \\
\hline
\end{tabular}




\section{FIGURE 3}

\section{Organizing Logics Combining in Action in Hypothetical Organization}

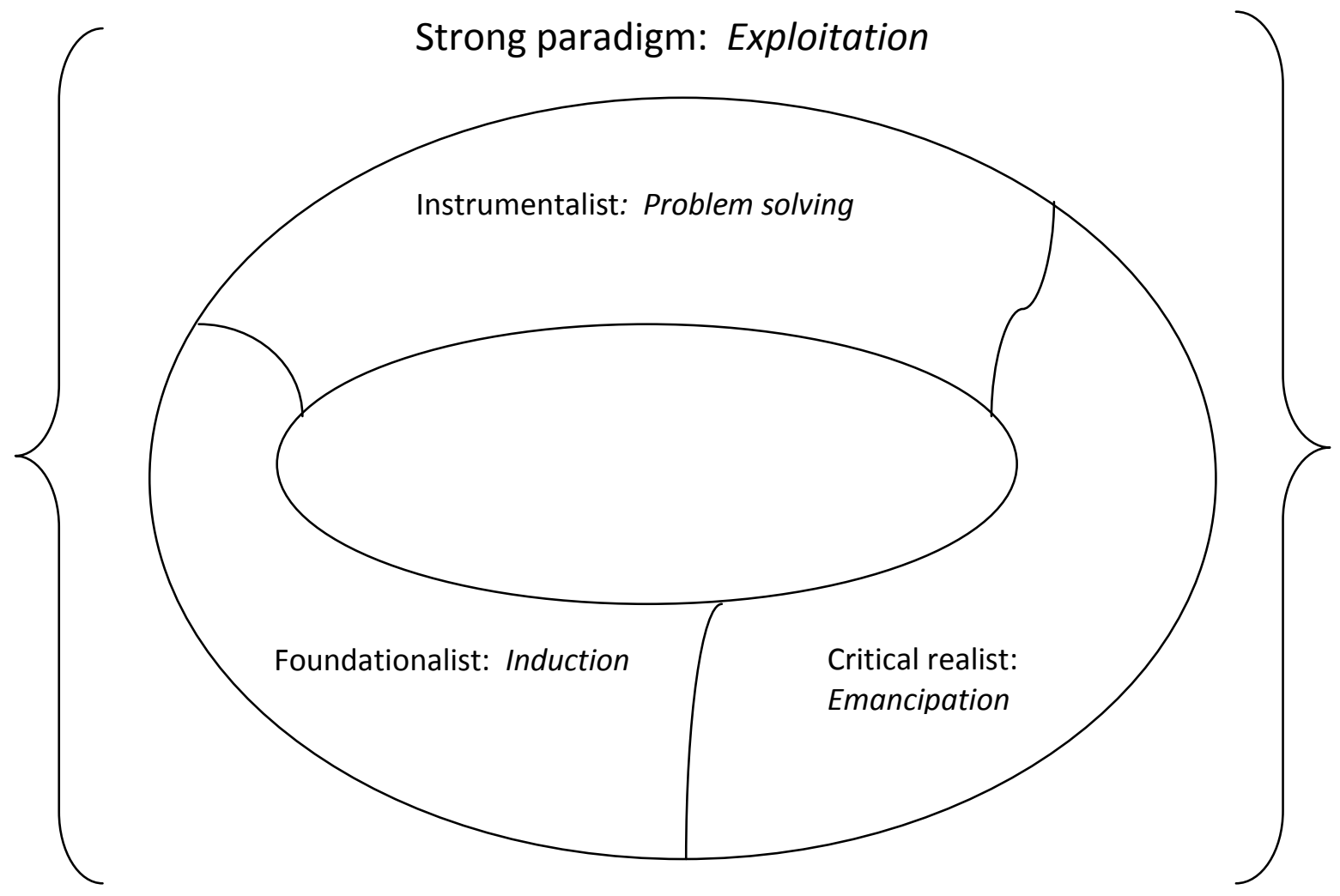


Martin Kilduff (mjkilduff@gmail.com) is Diageo Professor of Management Studies at the University of Cambridge. He received his $\mathrm{PhD}$ from Cornell University. Current research topics (besides philosophy of science theory) include organizational innovation, social network cognition, personality effects on network structuring, and the dark side of emotional intelligence.

Ajay Mehra (ajay.mehra@uky.edu) is an associate professor in management at the University of Kentucky. He received his PhD from Penn State. His research focuses on the relationship between psychology and the structure and dynamics of social networks.

Mary B. Dunn (mary.bowker.dunn@gmail.com) is a lecturer in management at the McCombs School of Business at The University of Texas at Austin. She received her PhD. from Boston College. Her research focuses on professionals' social networks, knowledge creation, and institutional logics and change.

Structural realist:

Pure research 